\title{
CORRELATION OF HAEMOLYTIC FACTORS AND HYDROXYUREA TREATMENT IN SICKLE CELL ANAEMIA WITH PULMONARY HYPERTENSION
}

\author{
Bharatsing D. Rathod, Sunil D. Bhaisare2, Keyur Kishor Dave ${ }^{3}$ \\ ${ }^{1}$ Associate Professor, Department of Medicine, GGMC, Mumbai. \\ ${ }^{2}$ Associate Professor, Department of Medicine, GGMC, Mumbai. \\ ${ }^{3}$ Former Resident, Department of Medicine, GMC, Nagpur.
}

\section{ABSTRACT}

\section{BACKGROUND}

Retrospective and prospective studies ${ }^{1-4}$ have shown that $20 \%-40 \%$ of adult sickle cell patients have evidence of pulmonary hypertension on 2D Echocardiography evaluation. It is also an independent risk factor for death in sickle cell anaemia. Various studies ${ }^{4-6}$ reported $40 \%$ - 50\% two-year mortality rate in sickle cell anaemia with pulmonary hypertension, which is quite high. Haemolysis is a proposed mechanism in development of PH in SS patients, while hydroxyurea has interesting relation with nitric oxide biology.

The objectives of this study are-1) Evaluation of haemoglobin level, WBC count, platelet count, reticulocyte count and their relationship with SS patients; 2) Evaluation of serum bilirubin, serum LDH in relation with PH in SS patients; and 3) To establish relation of HU treatment with PH in SS patients.

\section{MATERIALS AND METHODS}

It is a hospital-based cross-sectional study; 88 cases of Sickle Cell Anaemia (SS) diagnosed as SS patterned on Hb electrophoresis were evaluated for various haemolytic factors, rheological factors and treatment with hydroxyurea to establish their relationship with pulmonary hypertension in sickle cell anaemia patient (SS pattern on Hb electrophoresis) and grouped in 2 groups as SS with Pulmonary Hypertension (PH) and SS without PH by 2D Echocardiography evaluation with Tricuspid Regurgitant Jet Velocity (TRV) of $>2.5 \mathrm{~m} / \mathrm{s}$ and $<2.5 \mathrm{~m} / \mathrm{s}$ respectively.

\section{RESULTS}

There were 66 male and 22 female cases; 32 (36.36\%) cases had PH and 56 (63.64\%) cases were without PH. There was no significant age and gender relation with PH in SS. Mean number of hospital admissions in the past were $3.63 \pm 1.29$ in SS with PH and $2.76 \pm 1.08$ in SS without PH having highly significant difference ( $\mathrm{p}$ value $=0.001$ ). Mean duration of illness from diagnosis of SS was not significant. Mean number of blood transfusions received in the past in SS with PH were $2.21 \pm 1.82$ and $1.03 \pm 1.11$ in SS without PH with significant difference. There was no relation in number of vaso-occlusive crises in past with PH. Mean Haemoglobin was $7.63 \pm 0.69$ in SS with PH and $8.25 \pm 1.15$ gm/dL in SS without PH group. This difference was statistically significant. Reticulocytosis also had positive relation with PH. Biochemical parameters such as high serum Lactate Dehydrogenase (LDH) had statistically significant relation with PH. Patients of SS without PH receiving Hydroxyurea were 26.78\%, while only $6.25 \%$ of SS with PH patients were receiving Hydroxyurea. This difference was statistically significant. Zinc and Folic acid did not find significant difference in relation with $\mathrm{PH}$.

\section{CONCLUSION}

Serum LDH is a good laboratory marker of haemolysis as well as PH in SS patients along with low haemoglobin and reticulocytosis. It may be used as a predictor of PH in sickle cell anaemia patients. There is high risk of development of PH in those sickle cell anaemia patients who were not receiving hydroxyurea suggesting its use in SS patients for primary prevention of pulmonary hypertension in sickle cell anaemia.

\section{KEYWORDS}

Hydroxyurea in Sickle Cell Anaemia with PH, LDH in Sickle Cell Anaemia, Sickle Cell Disease Related Pulmonary Hypertension.

HOW TO CITE THIS ARTICLE: Rathod BD, Bhaisare SD, Dave KK. Correlation of haemolytic factors and hydroxyurea treatment in sickle cell anaemia with pulmonary hypertension. J. Evolution Med. Dent. Sci. 2017;6(60):4398-4402, D0I: $10.14260 /$ Jemds/2017/951

\section{BACKGROUND}

Retrospective and prospective studies ${ }^{1-4}$ have shown that $20 \%-40 \%$ of adult sickle cell patients have evidence of pulmonary hypertension on 2D Echocardiography evaluation.

Financial or Other, Competing Interest: None.

Submission 19-06-2017, Peer Review 14-07-2017,

Acceptance 20-07-2017, Published 27-07-2017.

Corresponding Author:

Dr. Sunil D. Bhaisare,

Associate Professor,

Department of Medicine,

GGMC, Byculla, Mumbai-400008.

E-mail: sunil18bhaisare@gmail.com

DOI: $10.14260 /$ jemds $/ 2017 / 951$
It is also an independent risk factor for death in sickle cell anaemia. Various studies ${ }^{4-6}$ reported $40 \%$ - 50\% two-year mortality rate in sickle cell anaemia with pulmonary hypertension, which is quite high.

A novel mechanism of the clinical sequelae of haemolysis and its effect on Nitric Oxide (NO) biology has been proposed as mechanism for $\mathrm{PH}$ in SS.7 $^{7}$ Other mechanisms are endothelin pathway, ${ }^{8-9}$ asplenia, procoagulant state, nocturnal hypoxaemia and iron overload.10-12

The therapeutic efficacy of Hydroxyurea (HU) is attributed to induction of foetal haemoglobin and potentially to reduction of white blood cells as well as platelet counts, improved rheology and decreased endothelial red blood cell adhesion. Investigators have demonstrated an interesting relationship between $\mathrm{HU}$ and N0.13-15 
Considering this background, we evaluated SS patients for various parameters like age, gender, haematological parameters such as haemoglobin, reticulocyte count, WBC count and platelet count, biochemical parameters like serum $\mathrm{LDH}$ and treatment with $\mathrm{HU}$, zinc and folic acid in relation to $\mathrm{PH}$.

\section{Objectives}

1) Evaluation of haemoglobin level, WBC count, platelet count, reticulocyte count and their relationship with $\mathrm{PH}$ in SS patients.

2) Evaluation of serum bilirubin, serum LDH in relation with PH in SS patients.

3) To establish relation of $\mathrm{HU}$ treatment with $\mathrm{PH}$ in SS patients.

\section{MATERIALS AND METHODS}

It was a hospital-based cross-sectional study of 88 Sickle cell anaemia (SS) patients fulfilling inclusion and exclusion criteria, admitted to Medical Intensive Care Unit and Medicine Wards at our tertiary care hospital, Central India, during the period of November 2008 to October 2010 randomly. Estimation of sample size was done in reference with assumption of $\mathrm{PH} 32 \%$ quoted by Gladwin et al ${ }^{4}$ with absolute precision of $5 \%$ and desired level of confidence interval of $95 \%$, estimated sample size was 384 while we evaluated 88 cases of SS. We included 88 cases of SCD patients having $\mathrm{Hb}$ electrophoresis report of SS pattern (i.e. identified cases of SS pattern).

\section{Inclusion Criteria}

SS patients aged $>12$ years.

\section{Exclusion Criteria}

Patients with an aetiology of PH other than SCD like valvular heart disease, congenital heart disease and connective tissue disorders.

Thorough clinical examination and history was noted. Patient's demographic characteristics like age and gender, duration of illness from time of diagnosis, number of blood transfusions received in the past and number of hospitalisations in the past were recorded. Investigations such as haemoglobin, WBC count, platelet count, reticulocyte count and serum bilirubin were done on admission. Serum LDH was done in all patients after steady state of illness (on discharge mostly at least after one week). 2D Echo with colour Doppler was done on each patient. TRV was used to estimate pulmonary arterial systolic pressure. Depending on TRV $>2.5 \mathrm{~m} / \mathrm{s}$ or $<2.5 \mathrm{~m} / \mathrm{s}$, they were grouped in 2 groups as SS with PH and SS without PH respectively. All patients were evaluated retrospectively regarding what treatment they were receiving like zinc, folic acid and HU.

\section{Statistical Analysis}

Data reported as Mean \pm SD when normally distributed. Discrete variables were expressed in actual number and percentage. For categorical data, Chi square test was used and Fisher exact test was used for small numbers.
For continuously distributed variables, student ' $\mathrm{T}$ ' test was used. $\mathrm{P}$ value of $<0.05$ was considered statistically significant, while $P$ value of $<0.001$ was considered highly significant. Statistical software SPSS Version 17 and Primer was used for analysis.

\section{RESULTS}

88 cases of SS were evaluated and grouped in two groups as SS with PH and SS without PH (Table 1). There were 66 males and 22 females; 32 (36.36\%) cases had PH and 56 (63.64\%) cases were without $\mathrm{PH}$. There was no significant relation of gender with PH. Maximum number of patients from both SS with PH and SS without PH were 20 - 29 years and $10-19$ years with no significant relation of age with $\mathrm{PH}$ (Table 2).

Difference of mean number of hospital admissions in SS with $\mathrm{PH}$ and SS without $\mathrm{PH}$ group was highly significant $(\mathrm{t}=3.384$ with 95 degrees of freedom, $\mathrm{p}=0.001$ ). Difference of mean number of blood transfusions received in SS with $\mathrm{PH}$ and SS without $\mathrm{PH}$ group was also significant $(\mathrm{t}=3.782$ with 95 degrees of freedom, $p<0.001$ ). Mean duration of illness from diagnosis of SCD and number of VOCs in past had no significant relation with PH (Table No. 3).

Among rheological factors difference of mean haemoglobin ( $\mathrm{t}=-\mathbf{2 . 7 7 4}$ with 95 degrees of freedom, $\mathrm{p}=0.007$ i.e. $<0.01$ ) and mean reticulocyte count in SS with PH group and SS without PH group was highly significant $(\mathrm{t}=6.031$ with 95 degrees of freedom, $\mathrm{p}<0.001$ ) (Table No. 4).

Mean serum LDH value in SS with PH group was higher as compared to SS without PH group with highly significant difference ( $t=5.368$ with 86 degrees of freedom, $p<0.001$ ). Although difference of mean serum bilirubin in SS with $\mathrm{PH}$ and in SS without PH group was not significant $(\mathrm{t}=1.675$ with 95 degrees of freedom, $\mathrm{p}=0.098$ ) (Table No. 5).

Patients were already receiving medications like Hydroxyurea (HU), Zinc and Folic Acid; $26.78 \%$ of SS without PH cases and only $6.25 \%$ of SS with $\mathrm{PH}$ were receiving HU. There was statistically significant difference in relation with $\mathrm{PH}$ in SS cases by Chi square test (4.271 with 1 degree of freedom, $p=0.039$ i.e. $<0.05$ ). Hence, patients of SS not on HU have a higher risk of PH. Zinc and Folic Acid did not find significant difference in relation with PH (Table 6).

\begin{tabular}{|c|c|c|c|}
\hline Group & Male & Female & P value \\
\hline $\begin{array}{c}\text { SS with PH } \\
(\mathrm{n}=32)\end{array}$ & $25(78.12 \%)$ & $7(21.88 \%)$ & 0.798 \\
\hline $\begin{array}{c}\text { SS without PH } \\
(\mathrm{n}=56)\end{array}$ & $41(73.21 \%)$ & $15(26.79 \%)$ & \\
\hline
\end{tabular}

Table 1. Gender Distribution and its Relation with PH

\begin{tabular}{|c|c|c|c|}
\hline Group & $\begin{array}{c}\text { Mean Age } \pm \text { SD } \\
\text { in Years }\end{array}$ & $\begin{array}{c}\text { Confidence } \\
\text { Interval }\end{array}$ & P value \\
\hline $\begin{array}{c}\text { SS with } \mathrm{PH} \\
(\mathrm{n}=32)\end{array}$ & $25.09 \pm 11.58$ & -3.027 to 4.067 & 0.771 \\
\hline $\begin{array}{c}\text { SS without } \mathrm{PH} \\
(\mathrm{n}=56)\end{array}$ & $24.57 \pm 5.08$ & & \\
\hline \multicolumn{3}{|c|}{ Table 2. Age Distribution and its Relation with PH } \\
\hline
\end{tabular}




\begin{tabular}{|c|c|c|c|c|}
\hline $\begin{array}{c}\text { Sl. } \\
\text { No. }\end{array}$ & Variables & $\begin{array}{c}\text { SS with PH } \\
\text { Mean } \pm \text { SD }\end{array}$ & $\begin{array}{c}\text { SS without } \\
\text { PH } \\
\text { Mean } \pm \text { SD }\end{array}$ & P value \\
\hline 1 & $\begin{array}{c}\text { Number of } \\
\text { hospital } \\
\text { admissions in } \\
\text { past }\end{array}$ & $6.12 \pm 2.184$ & $4.45 \pm 0.89$ & 0.001 \\
\hline 2 & $\begin{array}{c}\text { Duration of } \\
\text { illness from } \\
\text { diagnosis of SCD } \\
\text { in Years) }\end{array}$ & $4.24 \pm 4.16$ & $3.56 \pm 2.5$ & 0.340 \\
\hline 3 & $\begin{array}{c}\text { Number of blood } \\
\text { transfusions } \\
\text { received in past }\end{array}$ & $2.21 \pm 1.82$ & $1.03 \pm 1.11$ & $\mathbf{0 . 0 0 1}$ \\
\hline 4 & $\begin{array}{c}\text { Number of VOCs } \\
\text { in past }\end{array}$ & $3.03 \pm 1.31$ & $2.67 \pm 0.91$ & 0.132 \\
\hline \multicolumn{5}{|c|}{ Table 3. Clinical Variables and Relation with PH } \\
\hline
\end{tabular}

\begin{tabular}{|c|c|c|c|c|}
\hline $\begin{array}{c}\text { Sl. } \\
\text { No. }\end{array}$ & Variable & $\begin{array}{c}\text { SS with PH } \\
(\mathbf{n = 3 2}) \\
\text { Mean } \pm \text { SD }\end{array}$ & $\begin{array}{c}\text { SS without } \\
\text { PH (n=56) } \\
\text { Mean } \pm \text { SD }\end{array}$ & P value \\
\hline 1 & $\begin{array}{c}\text { Haemoglobin } \\
\text { (gm/dL) }\end{array}$ & $7.63 \pm 069$ & $8.25 \pm 1.15$ & 0.007 \\
\hline 2 & $\begin{array}{c}\text { WBC count } \\
\text { (/cu. mm) }\end{array}$ & $8251 \pm 1900.51$ & $7683 \pm 2605.36$ & 0.279 \\
\hline 3 & $\begin{array}{c}\text { Platelets count } \\
\text { lakh/cu. mm) }\end{array}$ & $2.97 \pm 1.18$ & $2.94 \pm 0.93$ & 0.895 \\
\hline 4 & $\begin{array}{c}\text { Reticulocyte } \\
\text { count (\%) }\end{array}$ & $1.66 \pm 0.74$ & $0.98 \pm 0.31$ & 0.001 \\
\hline \multicolumn{7}{|c|}{ Table 4. Haematological Variables and Relation with PH } \\
\hline
\end{tabular}

\begin{tabular}{|c|c|c|c|c|}
\hline $\begin{array}{c}\text { Sl. } \\
\text { No. }\end{array}$ & Variable & $\begin{array}{c}\text { SS with PH } \\
\text { (n=32) } \\
\text { Mean } \pm \text { SD }\end{array}$ & $\begin{array}{c}\text { SS without } \\
\text { PH (n=56) } \\
\text { Mean } \pm \text { SD }\end{array}$ & P value \\
\hline 1 & $\begin{array}{c}\text { Serum LDH } \\
\text { (IU/L) }\end{array}$ & $475.90 \pm 212.83$ & $303.50 \pm 85.51$ & 0.001 \\
\hline 2 & $\begin{array}{c}\text { Serum } \\
\text { Bilirubin } \\
\text { (mg/dL) }\end{array}$ & $1.639 \pm 0.69$ & $1.39 \pm 0.66$ & 0.098 \\
\hline \multicolumn{4}{|c|}{ Table 5. Biochemical Variables and their Relation with PH } \\
\hline
\end{tabular}

\begin{tabular}{|c|c|c|c|c|}
\hline $\begin{array}{c}\text { Sl. } \\
\text { No. }\end{array}$ & Medicines & $\begin{array}{c}\text { SS with PH } \\
\text { (n=32) }\end{array}$ & $\begin{array}{c}\text { SS without } \\
\text { PH (n=56) }\end{array}$ & P value \\
\hline 1 & Hydroxyurea & $2(6.25 \%)$ & $15(26.78 \%)$ & $\mathbf{0 . 0 3 9}$ \\
\hline 2 & Folic Acid & $28(87.5 \%)$ & $48(85.71 \%)$ & 0.930 \\
\hline 3 & Zinc & $26(81.25 \%)$ & $44(78.57 \%)$ & 0.980 \\
\hline \multicolumn{4}{|c|}{ Table 6. Treatment of SCD and its Relation with PH } \\
\hline
\end{tabular}

\section{DISCUSSION}

There were 88 cases of sickle cell anaemia; 32 (36.36\%) had $\mathrm{PH}$ and $56(63.64 \%)$ cases had no PH. So prevalence of PH was $36.36 \%$ in SS cases in our study. Ataga et $\mathrm{al}^{3}$ and De Castro et al ${ }^{16}$ reported PH ranging from $30 \%-36 \%$ in SCD. Age and gender have no significant relation with $\mathrm{PH}$ in SS patients in our study. The mean age was $25.09 \pm 11.58$ years and $24.57 \pm 5.08$ years in patients of SS with PH and SS without PH respectively. Mustafa San et al ${ }^{17}$ reported similar findings, while some studies ${ }^{4,18}$ found higher mean age ranging from $37 \pm 13$ years to $40 \pm 14$ years in SS patients with no significant difference in relation to $\mathrm{PH}$.

Patricia Houston-Yu and colleagues ${ }^{19}$ found frequent hospitalisation in SS with PH cases with significant difference. In our study, mean number of hospitalisations were $3.63 \pm$ 1.29 and $2.76 \pm 1.08$ in SS with $\mathrm{PH}$ and SS without $\mathrm{PH}$ respectively having highly significant relation with $\mathrm{PH}(\mathrm{p}$ value $=0.001$ ). A study by Gladwin and co-workers ${ }^{4}$ showed significant relation of blood transfusions in SS patients stating patients requiring more blood transfusions had $\mathrm{PH}$, while patients without $\mathrm{PH}$ had required lesser blood transfusions. We found mean number of blood transfusions received were $2.21 \pm 1.82$ in SS with $\mathrm{PH}$ and $1.03 \pm 1.11$ in SS without PH with highly significant difference ( $p$ value $=0.001$, i.e. $<0.01$ ) Patients of sickle cell anaemia requiring frequent hospitalisation or more blood transfusions have either haemolysis, acute chest syndrome, VOCs or other complications of the disease such as auto-splenectomy procoagulant state and iron overload which are the pathophysiologic factors responsible for $\mathrm{PH}$ in SS anaemia patients. $7,10,12,20$

Studies $4,21,22$ found significant higher level of serum LDH in SS cases with PH with values of $508 \pm 51 \mathrm{IU} / \mathrm{L}, 491 \pm 196$ $\mathrm{IU} / \mathrm{L}$ and $488 \pm 191 \mathrm{IU} / \mathrm{L}$ respectively. This was $475.9 \pm$ $212.13 \mathrm{IU} / \mathrm{L}$ in our study with significant difference when compared to SS without PH group. Naoman et al ${ }^{18}$ and Castro 0 et al $^{6}$ demonstrated low haemoglobin and reticulocytosis having significant relation with PH in SCD. In our study, mean Hb was $7.63 \pm 0.69 \mathrm{gm} / \mathrm{dL}$ and mean reticulocyte count was $1.66 \pm 0.74 \%$ in SS with PH group having significant relation when compared to SS without PH group.

Higher serum $\mathrm{LDH}$, reticulocytosis and low $\mathrm{Hb}$ are due to chronic haemolysis of RBCs in SCD, which has effect on NO biology resulting in PH.7 Chronic haemolysis leads to cell-free plasma haemoglobin which scavenges NO. In addition, haemolysis releases Arginase, which degrades Arginine the substrate for endothelial NO synthase resulting in decreased NO production. ${ }^{23}$ No is a potent vasodilator and plays an important role in vascular endothelial haemostasis. Its depletion leads to vasoconstriction, endothelial dysfunction, platelet activation, oxidative stress and proliferative vasculopathy that ultimately leads to PH in SCD and other haemolytic anaemias.7,24 Another mechanism is endothelial pathway. Endothelin-1 promotes pulmonary artery smooth muscle contraction, proliferation and hypertrophy. It is overexpressed in SCD, potentially causing the development of $\mathrm{PH}^{8-9}$ Other factors are asplenia, procoagulant state, nocturnal hypoxaemia and iron overload. ${ }^{10-12}$

$26.78 \%$ patients of SS without PH group were on $\mathrm{HU}$ as compared to $6.25 \%$ patients of SS with $\mathrm{PH}$ group. The difference was statistically significant. Hence, HU may have a role in preventing $\mathrm{PH}$ in SS patients. Ataga et $\mathrm{al}^{3}$ and De Castro et al ${ }^{16}$ had $33 \%$ and $29 \%$ of SCD with pH on HU respectively, while $62 \%$ and $70 \%$ of patients of SCD without $\mathrm{PH}$ were on HU. Both studies found significant difference. There was no significant difference in relation to $\mathrm{pH}$ for folic acid and zinc treatment.

Although the exact mechanism of action remains uncertain, the therapeutic efficacy of $\mathrm{HU}$ is attributed to induction of foetal haemoglobin and potentially to reduction of white blood cell and platelet counts, improved rheology and decreased endothelial red blood cell adhesion. This has 
been shown to reduce painful events and acute chest syndromes as well as improve survival in sickle cell anaemia patients. ${ }^{25-27}$ Several investigators have also demonstrated an interesting relationship between $\mathrm{HU}$ and $\mathrm{NO}$, that $\mathrm{HU}$ increases the level of $\mathrm{NO}$ which plays a role in $\mathrm{HU}$-induction of foetal haemoglobin. Given the critical role of NO depletion in the pathogenesis of $\mathrm{PH}$ in SCD, these observations may support important role of $\mathrm{HU}$ in treatment of PH in SCD. ${ }^{13-15}$

\section{Limitations of Study}

Being small sample size, it has limitations and requires large randomised trials.

\section{CONCLUSION}

Serum LDH in steady state of disease is a good laboratory marker of haemolysis as well as pulmonary hypertension in sickle cell anaemia along with low haemoglobin and reticulocytosis. It may be used as predictor of PH in SCD patients. As the survival of sickle cell anaemia patients is increasing, the complication like pulmonary hypertension is more evident nowadays. Once the pulmonary hypertension develops, the morbidity and mortality in SCD increases as secondary prevention by various medications for $\mathrm{PH}$ still have no promising results. Hydroxyurea reduces the risk of PH in sickle cell disease. Hence, can each patient of sickle cell anaemia, particularly young adults be put on hydroxyurea to primarily prevent this complication? To answer this, it may require formulation of some solid guidelines to put these patients on hydroxyurea other than already existing guidelines after doing large randomised trials.

\section{REFERENCES}

[1] Casrto O. Systemic fat embolism and pulmonary hypertension in sickle cell disease. Hematol Oncol Clin North Am 1996;10(6):1289-303.

[2] Sutton LL, Castro O, Cross DJ, et al. Pulmonary hypertension in sickle cell disease. Am J Cardiol 1994;74(6):626-8.

[3] Ataga KL, Sood N, de Gent G, et al. Pulmonary hypertension in sickle cell disease. Am J Med 2004;117(9):665-9.

[4] Gladwin MT, Sachdev V, Jison ML, et al. Pulmonary hypertension as a risk factor for death in patients with sickle cell disease. N Eng J Med 2004;350(9):886-95.

[5] Powars D, Weidman JA, Odom-Maryon T, et al. Sickle cell chronic lung disease: prior mortality and the risk of pulmonary failure: Medicine (Baltimore) 1988;67(1):66-76.

[6] Castro 0, Hoque M, Brown BD. Pulmonary hypertension in sickle cell disease: cardiac catheterisation results and survival. Blood 2003;101(4):1257-61.

[7] Rother RP, Bell L, Hillmen P, et al. The clinical sequelae of intravascular hemolysis and extravascular plasma hemogobin: a novel mechanism of human disease. JAMA 2005;293(13):1653-62.

[8] Ergul S, Brunson CY, Hutchinson J. Vasoactive factors in sickle cell disease: in vitro evidence for endothelin1-mediated vasoconstriction. Am J Hematol 2004;76(3):245-51.
[9] Graido-Gonzalez E, Doherty JC, Bergreen EW, et al. Plasma endothelin-1, cytokine and prostaglandin-E2 levels in sickle cell disease and acute vaso-occlusive sickle crisis. Blood 1998;92(7):2551-5.

[10] Ataga KL, Orringer EP. Hypercoagulability in sickle cell disease: a curious paradox. Am J Med 2003;115(9): 721-8.

[11] Needleman JP, Franco ME, Varlotta L. Mechanism of oxyhemoglobin desaturation in children and adolescents with sickle cell disease. Pediatric Pulmonol 1999;28(6):418-22.

[12] Neumayr L, Morris C, Harmatz P. Pulmonary hypertension in chronically transfused patients with sickle cell and thalassemia: a report from multicentre study of iron overload (Abstract). Presented at the $29^{\text {th }}$ Annual Meeting of the National sickle cell disease programme, Memphis, TN. April 8-12, 2006.

[13] Cokic VP, Smith RD, Beleslin- Cokic BB, et al. Hydroxyurea induses fetal haemoglobin by the nitric oxide dependent activation of soluble guanylyl cyclase. J Clin investigation 2003;111(2):231-9.

[14] Nahavandi M, Wyche MQ, Perlin E, et al. Nitric oxide metabolites in sickle cell anemia patients after oral administration of hydroxyurea. Hemoglobinopathy Hematology 2000;5(4):335-9.

[15] Palelli R, Taira J, Cook JA, et al. Hydroxyurea reacts with heme proteins to generate nitric oxide. Lancet 1996;347(9005):900.

[16] De Castro LM, Jonassaint JC, Graham FL, et al. Pulmonary hypertension associated with sickle cell disease: clinical and laboratory endpoints and disease outcomes. Am J Hematol 2008;83(1):19-25.

[17] San M, Demirtas M, Burgul R. Left ventricular systolic and diastolic functions in patients with sickle cell anemia. Int J Angiology 1998;17:185-7.

[18] Naoman SG, Nouraie M, Castro OL, et al. Echocardiographic findings in patients with sickle cell disease. Ann of Hematol 2010;89(1):61-6.

[19] Houston-Yu P, Rana SR, Beyer B, et al. Frequent and prolonged hospitalisation: a risk factor for early mortality in sickle cell disease patients. Am J Hematol 2003;72(3):201-3.

[20] Hsu LL, Champion HC, Campbell-Lee SA, et al. Hemolysis in sickle cell mice causes pulmonary hypertension due to global impairment in nitric oxide bioavailability. Blood 2007;109(7):3088-98.

[21] Kato GJ, McGowan V, Machado RF, et al. Lactate dehydrogenase as a biomarker of hemolysis associated nitric oxide resistance in priapism, leg ulceration, pulmonary hypertension and death in patients with sickle cell disease. Blood 2006;107(6):2279-85.

[22] Liem RL, Young LT, Thompson AA, Tricuspid regurgitant jet velocity is associated with hemolysis in children and young adults with sickle cell disease evaluated for pulmonary hypertension. Haematologica 2007;92(11):1549-52. 
[23] Morris CR, Morris SM, Hagar W, et al. Arginine therapy: a new treatment for pulmonary hypertension in sickle cell disease? Am J Respir Crit Care Med 2003;168(1):63-9.

[24] Gladwin MT, Kato GJ. Cardiopulmonary complications of sickle cell disease: role of nitric oxide and haemolytic anemia. Hematol Am Soc Hematol Edu Programme 2005;51-7.

[25] Steinberg MH, Barton F, Castro 0, et al. Effect of hydroxyurea on mortality and morbidity in adult sickle cell anemia: risks and benefit up to 9 years treatment. JAMA 2003;289(13):1645-51.
[26] Charache S, Terrin ML, Moore RD, et al. Effect of hydroxyurea on the frequency of painful crises in sickle cell anemia. Investigators of the multicenter study of hydroxyurea in sickle cell anemia. N Eng J Med 1995:332(20):1317-22.

[27] Kinney TR, Helms RW, O'Branski EE, et al. Safety of hydroxyurea in children with sickle cell anemia: results of HUG-KIDS study, a phase I/II trial. Pediatric Hydroxyurea group. Blood 1999;94(5):1550-4. 